\title{
Impacts of Political Connections on Private Enterprise Performance in China and the Analysis of Mediating Effects
}

\author{
Yang Wen ${ }^{1}$ \\ ${ }^{1}$ School of Economics, Central University of Finance and Economics, Beijing, China \\ Correspondence: Yang Wen, School of Economics, Central University of Finance and Economics, Beijing, \\ China. Tel: 86-138-1038-7959. E-mail: yangwen@cufe.edu.cn
}

Received: September 19, 2020

Accepted: October 8, 2020

Online Published: October 10, 2020

doi:10.5539/ijef.v12n11p28

URL: https://doi.org/10.5539/ijef.v12n11p28

\begin{abstract}
Based on data of Chinese Private Enterprises Survey (CPES) from 2006-2014, this paper uses OLS model and other empirical methods to estimate the impacts of political connections on private enterprise performance in China, as well as heterogeneous effects and mediating effects of different types of political connections on tax burden and non-productive activities expense. The results show that, political connections contribute significantly to private enterprises. Compared with previous political connections, like working experiences in state-owned enterprises and government-affiliated institutions, current political connections, like deputies to the NPC or members of CPPCC, have played better and further roles in enterprise performance. Tax burden and non-productive activities expense have a mediation effect in the relationship between political connections and enterprise performance. This study replenishes new evidence to describe how political connections affect private enterprise performance in China, and partly explains why private enterprises are keen on setting up political connections, which may provide valuable tips to foster a new type of cordial and clean relationship between government and business in China.
\end{abstract}

Keywords: private enterprises, different political connections, influential mechanism, enterprise performance

\section{Introduction}

Since the reform and opening up, private economy and private enterprises in China have made outstanding contributions to the development of national economy. In recent years, there appears to be some dubious and denial comments on the private sector, such as "the private sector out of the market" and "new theory of public-private partnership". In November 2018, Chairman Xi Jinping confirmed the importance of the private sector and private enterprises in China's economic system, and proposed supportive policies of abating the tax burden, easing financing difficulty and financing costs, and fostering a fair and justice environment, setting up a new type of cordial and clean relationship between government and business to reinvigorate future development of private enterprises. Meanwhile, fruitful achievements have been brought from studies about private enterprises concerned with social capitals (Yang et al., 2015), scale of enterprises (Zhang et al., 2015), political connections (He, 2019) and tax subsidies from government (Peng et al., 2019). Under the background of traditional Chinese culture and developing economy system, impacts and mechanism of political connections on enterprise performance in China still draws much attention.

What kind of influence does political connections have on private enterprise performance in China? Existing research finds that with incomplete formal structure such as law systems, political connections in private enterprises, as an official and substituted mechanism, could gain policy resource and assistance, thereby affecting allocation efficiency, protecting its own property right,relieving the financing constraint, lightening the tax burden, dropping down the obstruction of access to government controlling system, and promoting enterprise performance (Niessen \& Ruenzi, 2010; Li \& Xu, 2012). And also, some studies have arrived the conclusion that political connections may increase enterprises costs, for example, with more risks on enterprises' management and more policy burdens (Peng et al., 2014), and harm enterprise credits and capital market efficiency (Li et al., 2013). Previous studies mainly target at Chinese private listed companies. Actually, those unlisted private companies have even stronger motivations to build up political connections. However, this paper finds that, previous studies are still lack of adequate analysis that political connections' influence on performance mechanism in private enterprises. Different from previous studies, this paper is based on some existing theories 
and uses CPES data to focus on analyzing the role of the dual relationship between political connections and private enterprise performance, as well as analyzing the role of tax burden and unproductive expenditure in the relationship between them. This paper tries to further enrich theoretical research on political connections and the performance of Chinese private enterprises.

\section{Literature Review and Hypothesis}

Empirical analysis shows that the phenomenon of enterprises seeking political connections is widespread worldwide (Faccio, 2006). Under the background of China's transformational economy, political connections have unique value to Chinese private enterprises. The inertia of traditional planned economy thoughts makes the government departments still maintain the scarce resources which enterprises depend for survival, and private enterprises still face obvious or rigid discriminations or development bottlenecks in property rights protection, industry entry barriers and financing constraints, which leads to slow expansion of private enterprises. The establishment of political connections helps private enterprises to gain access to credit loan, easier access to government subsidies and supports, enter high-margin monopoly industries, expand business investment, improve efficiency of enterprises investment ( $\mathrm{Li}$ et al., 2007, Chen \& Zhu, 2009), and boost enterprise performance and increase values (Su et al., 2013).

Can various types of political connections have different effects on enterprise performance? This paper classifies political connections into previous connections and current connections. Previous political connections refer to the work experience of private entrepreneurs in government or public institutions or state-owned or collective enterprises. Current political connections mainly refer to participation of private entrepreneurs in politics, such as deputies to NPC or members of CPPCC. For those private enterprises with current political connections, the status of a private entrepreneur's deputy to the NPC or a member of the CPPCC can on the one hand enhance their own reputation and status, and put an invisible label valued by the government on their enterprises. On the other hand, entrepreneurs can thus participate in the research and design of major national policies and important issues, understand the latest national policy resource orientation, seize the opportunity to obtain more government resources, explore new business opportunities for corporate development, and find new growth points for enterprises operating performance. Without current political connections, private entrepreneurs' work experiences in party and government institutions or state-owned collective enterprises also can obtain resources by asking for a hand from former colleagues or friends who have powerful capability on political operation. What's more, current political connections are more stable and institutional connections than previous political connections based on personal social network relationships. Based on that, this paper presents the following hypothesis:

Hypothesis 1: For private enterprises with political connections are better in performance, and positive influence of current political connections on performance of private enterprises is greater than that of previous political connections.

From exiting literature reviews, we find that political connections can influence performance of private enterprises through a variety of paths. This paper takes unproductive expenditure and tax burden as study point, and discusses whether both have a role in political connections and the performance of private enterprises. At present, many tax policies in China still have large flexibility, added with the tax competition between local governments, so that local governments and government officials still have certain control power and decision-making power on enterprise tax collections and tax concessions. In this case, political connections of private entrepreneurs may further affect enterprises' performance by affecting tax burden. Zimmerman (1983) applies "political power hypothesis" and "political costs hypothesis" on the effects of enterprises size on tax burden. "Political costs hypothesis" considers that tax burden is a form of political costs. On the contrary, "political power hypothesis" holds that larger enterprises have more resources, form greater political power, and enjoy lower actual tax rates. This paper prefers "political cost hypothesis". Specifically speaking, private enterprises with political connections, no matter previous connections in government or public institutions or state-owned or collective enterprises, or being members of NPC or CPPCC with current political connections, both are with higher social reputation or official network resources, which may gain greater attentions from sectors included financial or taxation departments and affect the decision-making of private enterprise tax planning. As taxes and fees are important sources of national fiscal revenue, local governments may intervene in the tax planning and taxation of private enterprises, especially those with political connections, to alleviate lack of local construction funds, thereby increasing the tax burden of private enterprises. When the unreasonable burdens of taxes and fees exceed the scope of private enterprises, private enterprises may deliberately reduce politically-related investment, and instead invest more energy and funds in production field, improve independent competitiveness of enterprises, and then improve enterprise performance. In view of this, this paper 
presents the following hypothesis:

Hypothesis 2: Tax burden plays a mediating role in the process of the overall political connections and different types of political connections to affect the performance of private enterprises.

Public relations hospitality and apportionment expenses are non-productive activities expenses that consume resources and are an unreasonable burden on enterprises. On one hand, government controls the important resources needed by enterprises, private enterprises based on the consideration of "Stockholders Interest First" may be motivated to establish political connections, actively or passively participate in or accept government's assigned tasks of public utilities such as poverty alleviation and infrastructure construction, and pay additional "political connection costs". On the other hand, private enterprises that already have political connections will have a strong motivation to maintain hard-won political connections, especially when they lack competitiveness of intangible assets such as technology and brand, they may choose to actively consume a lot of non-production time and entertainment expenses for external public relations, resulting in private enterprises' expenditures on productive activities giving way to expenditures on non-productive activities, affecting corporate earnings. That is to say, the closer the political connections, the greater the costs, which may offset the benefits generated by political connection (Faccio, 2006). Even so, while increasing the expenditure of non-productive activities of private enterprises, political connections also achieve the purpose of establishing or maintaining good relations with the government, such as helping enterprises to improve efficiency of administrative agencies and obtain higher quality services (Leys, 1965; Bailey, 1966).It is convenient to obtain other aspects of resource advantages, and still has a positive effect on corporate performance. From the perspective of different types of political connections, the channels and quality of access to information and resources with previous political connections often depend on the degree of trust in the relationship between individuals and the government. Such political connections that rely on personal trust require efforts and time, "public relations" and other non-productive activities are spent to obtain information and resources. Current political connections can establish an institutionalized trust relationship. Private entrepreneurs are more likely to have prior access to policy information related to enterprise development, and reduce the time and energy to search for policy information. In view of this, this paper presents the following hypothesis:

Hypothesis 3: Non-productive activity expenditure plays a mediating role in the process of the overall political connection and different types of political connections to affect the performance of private enterprises.

\section{Empirical Analysis}

\subsection{Model Framework and Analysis of Regression}

According to the above discussions, this paper formulates the equation (1) to examine the influence of political connections on private enterprise performance. The main variable names and definitions are shown in Table 1, and the results are listed in Table 2.

$$
\begin{aligned}
& \text { ROA }_{i}=\alpha+\beta_{1} x_{i}+\beta_{2} \text { empl }_{i}+\beta_{3} \text { agec }_{i}+\beta_{4} \text { alra }_{i}+\beta_{5} \text { ltass }_{i}+\beta_{6} \text { ind }_{i} \\
& +\beta_{7} \text { gend }_{i}+\beta_{8} \text { age }_{i}+\beta_{9} \text { edu }_{i}+\text { year }+ \text { prov }+ \text { ind }+\varepsilon_{i}
\end{aligned}
$$

\begin{tabular}{|c|c|c|c|}
\hline & code & Name & Definition \\
\hline $\begin{array}{c}\text { Dependent } \\
\text { variables }\end{array}$ & ROA & performance & $\begin{array}{l}\text { ROA means return on assets, which means dividing a company's net income by } \\
\text { total assets. }\end{array}$ \\
\hline \multirow{4}{*}{$\begin{array}{l}\text { Independent } \\
\text { variable }\end{array}$} & pcon & All political connections & $\begin{array}{l}\text { If owners of enterprises have/had working experiences in government, public } \\
\text { institutions, state owned or collective enterprises, NPC and CPPCC, pcon=1; if not, } \\
\text { pcon=0 }\end{array}$ \\
\hline & fpoc & Previous political connections & $\begin{array}{l}\text { Having working experiences in government, public institutions and state-owned or } \\
\text { collective enterprises, fpoc }=1 \text {; otherwise, fpoc }=0\end{array}$ \\
\hline & cpoc & Current political connections & Having working experience in NPC and CPPCC, $c$ poc $=1 ; \mathrm{cpoc}=0$ \\
\hline & empl & enterprises scale & Natural logarithm of the number of employers \\
\hline \multirow{4}{*}{$\begin{array}{l}\text { Enterprises } \\
\text { control } \\
\text { variables }\end{array}$} & agec & enterprises age & Current year minus birth year \\
\hline & alra & asset-liability ratio & Total debt / total assets of the year \\
\hline & ltass & scale of assets & Natural logarithm of total assets in this year \\
\hline & indc & industrial position & The proportion of the enterprise's operating income to total revenue of the industry. \\
\hline \multirow{3}{*}{$\begin{array}{l}\text { Entrepreneurs } \\
\text { control } \\
\text { variables }\end{array}$} & gend & gender & 1 for male, 0 for female \\
\hline & age & age & Current year minus birth year \\
\hline & edu & education & $\begin{array}{l}1 \text { for primary school, } 2 \text { for junior high school, } 3 \text { for high school and secondary } \\
\text { school, } 4 \text { for junior college, } 5 \text { for university, } 6 \text { for postgraduate education }\end{array}$ \\
\hline
\end{tabular}

Table 1. Variable names and definitions 
Table 2. Political connections and performance in private enterprises

\begin{tabular}{|c|c|c|c|}
\hline $\begin{array}{c}\text { dependent variables } \\
\text { ROA }\end{array}$ & Model (1) & Model (2) & Model (3) \\
\hline pcon & $\begin{array}{c}5.531 * * * \\
(3.76)\end{array}$ & & \\
\hline fpoc & & $\begin{array}{c}4.638 * * * \\
(4.00)\end{array}$ & \\
\hline сpoc & & & $\begin{array}{c}5.676^{* * * *} \\
(4.81)\end{array}$ \\
\hline empl & $\begin{array}{c}12.369^{* * *} \\
(17.09)\end{array}$ & $\begin{array}{c}12.518 * * * \\
(17.32)\end{array}$ & $\begin{array}{c}12.110 * * * \\
(16.92)\end{array}$ \\
\hline agec & $\begin{array}{l}0.164 \\
(1.37)\end{array}$ & $\begin{array}{c}0.210^{*} \\
(1.74)\end{array}$ & $\begin{array}{l}0.134 \\
(1.12)\end{array}$ \\
\hline alra & $\begin{array}{c}-0.078 * * * \\
(-4.06)\end{array}$ & $\begin{array}{c}-0.078 * * * \\
(-4.07)\end{array}$ & $\begin{array}{c}-0.076 * * * \\
(-3.97)\end{array}$ \\
\hline ltass & $\begin{array}{c}-13.664 * * * \\
(-21.86)\end{array}$ & $\begin{array}{c}-13.593 * * * \\
(-21.74)\end{array}$ & $\begin{array}{c}-13.811 * * * \\
(-21.83)\end{array}$ \\
\hline indc & $\begin{array}{c}0.639 * * * \\
(3.27)\end{array}$ & $\begin{array}{c}0.639 * * * \\
(3.28)\end{array}$ & $\begin{array}{c}0.642 * * * \\
(3.25)\end{array}$ \\
\hline gend & $\begin{array}{l}-0.149 \\
(-0.09)\end{array}$ & $\begin{array}{l}-0.008 \\
(-0.00)\end{array}$ & $\begin{array}{l}-0.078 \\
(-0.04)\end{array}$ \\
\hline age & $\begin{array}{l}-0.078 \\
(-1.10)\end{array}$ & $\begin{array}{l}-0.091 \\
(-1.28)\end{array}$ & $\begin{array}{l}-0.046 \\
(-0.66)\end{array}$ \\
\hline edu & $\begin{array}{c}1.592 * * * \\
(3.06)\end{array}$ & $\begin{array}{c}1.548 * * * \\
(2.95)\end{array}$ & $\begin{array}{c}1.708 * * * \\
(3.28)\end{array}$ \\
\hline _cons & $\begin{array}{c}47.819 * * * \\
(8.77)\end{array}$ & $\begin{array}{c}48.737 * * * \\
(8.96)\end{array}$ & $\begin{array}{c}50.089 * * * \\
(9.22)\end{array}$ \\
\hline province & control & control & control \\
\hline industry & control & control & control \\
\hline year & control & control & control \\
\hline $\mathrm{N}$ & 7872.000 & 7872.000 & 7872.000 \\
\hline $\mathrm{r} 2$ & 0.173 & 0.173 & 0.174 \\
\hline
\end{tabular}

Note. $\mathrm{t}$ statistics in parentheses, $* \mathrm{p}<0.1, * * \mathrm{p}<0.05$, *** $\mathrm{p}<0.01$.

In Table 2, independent variables from model (1) to model (3) are total political connections, previous political connections and current political connections, and the remaining control variables are the same. From the regression results, both the overall political connections and the classified political connections have a significant positive impact on the performance of private enterprises. Among them, the performance of politically connected enterprises is significantly higher than that of non-politically connected enterprises, and the performance of current politically connected private enterprises is significantly higher than that of previous politically connected private enterprises. Therefore, hypothesis 1 is certified by the statistical results.

\subsection{Endogenous Test}

Because the direct use of OLS regression may have problems of self-selection bias and missing variables, the results obtained by the regression may not be consistent and effective. In order to alleviate these problems, endogenous problem test is needed. This section uses two methods to test whether there is endogenity, including propensity score matching method and proxy variable test method. (1) Propensity score matching method. When estimating the impact of political connections on the performance of private enterprises, the endogenous problem may be due to non-random selection of the two types of entrepreneurs with and without political connections, and there are systemic differences. The method of propensity score matching attempts to match by certain characteristic variables, and finds two sets of samples that are approximately random and comparable as much as possible, so as to conduct causality testing. (2) Proxy variable test for missing variables. This method solves problems caused by missing variables by looking for proxy variables. From a practical point of view, the entrepreneur's personal ability will affect whether he has political connection. If a suitable variable can be found to reflect the entrepreneur's ability, it can be seperated from the residual, so that the residual term is no longer related to political correlations of the independent variables. Therefore, in this section, the entrepreneur and his 
family's shareholding ratio (ownp) is used as a proxy variable to identify the entrepreneur's personal ability, and equation (2) is established. The lower the shareholding ratio of entrepreneurs and their family members, the higher the external evaluation of their capabilities, which is more conducive to promoting the growth and development of the enterprise. The results of the robustness test are shown in Table 3 and Table 4.

Table 3. Propensity score matching results

\begin{tabular}{ccccccccc}
\hline & Variable & Sample & Treated & Controls & Difference & S.E. & T-stat \\
\hline Total & ROA & Unmatched & 23.028 & 21.592 & 1.436 & 1.410 & 1.020 \\
Political connections & & ATT & 23.028 & 18.432 & 4.596 & 2.203 & $2.090^{* *}$ \\
Previous Political & \multirow{2}{*}{ ROA } & Unmatched & 23.716 & 21.159 & 2.556 & 1.170 & $2.190^{* *}$ \\
connections & & ATT & 23.716 & 19.569 & 4.146 & 1.499 & $2.770^{* * *}$ \\
Current Political & \multirow{2}{*}{ ROA } & Unmatched & 23.294 & 22.146 & 1.148 & 1.139 & 1.010 \\
connections & & ATT & 23.294 & 18.754 & 4.540 & 1.530 & $2.970^{* * *}$ \\
\hline
\end{tabular}

Note. $\mathrm{t}$ statistics in parentheses, $* \mathrm{p}<0.1, * * \mathrm{p}<0.05$, *** $\mathrm{p}<0.01$.

The regression equation (2) after adding the proxy variable (ownp) of the shareholding ratio of entrepreneurs and family members is as follows. The regression results are shown in Table 4.

$$
\begin{aligned}
& \text { ROA }_{i}=\alpha+\beta_{1} x_{i}+\beta_{2} \text { empl }_{i}+\beta_{3} \text { agec }_{i}+\beta_{4} \text { alra }_{i}+\beta_{5} \text { ltass }_{i}+\beta_{6} \text { ind }_{i} \\
& +\beta_{7} \text { gend }_{i}+\beta_{8} \text { age }_{i}+\beta_{9} \text { edu }_{i}+\beta_{10} \text { ownp }_{i}+\text { year }+ \text { prov } \text { ind }+\varepsilon_{i}
\end{aligned}
$$

Table 4. The influence of political connections on the performance of private enterprises (proxy variable)

\begin{tabular}{cccc}
\hline $\begin{array}{c}\text { Dependent variables } \\
\text { ROA }\end{array}$ & Model (1) & Model (2) & Model (3) \\
\hline pcon & $5.517 * * *$ & & \\
& $(3.75)$ & $4.398 * * *$ & $6.035^{* * *}$ \\
fpoc & & $(3.75)$ & $(5.08)$ \\
& & & $-0.062^{* * * *}$ \\
cpoc & & & $(-3.14)$ \\
& $-0.053^{* * *}$ & $-0.047 * * *$ & yes \\
ownp & $(-2.69)$ & $(-2.37)$ & control \\
& yes & yes & control \\
control variables & control & control & control \\
province & control & control & 7872.000 \\
industry & control & control & 0.175 \\
year & 7872.000 & 7872.000 & 0.174 \\
N & 0.174 & &
\end{tabular}

Note. $\mathrm{t}$ statistics in parentheses, $* \mathrm{p}<0.1, * * \mathrm{p}<0.05, * * * \mathrm{p}<0.01$.

In summary, in order to alleviate the endogeneity of the basic model, this paper uses propensity score matching and proxy variables respectively to deal with the endogeneity problem. The empirical results further support the regression results of the basic model.

\subsection{Robustness Test}

In order to ensure the reliability of the basic regression results, this paper adopts two methods of adding institutional environmental factor measurement indicators and replacing the sample size to test the robustness of the basic model.

First of all, China's provincial marketization index measured by Fan Gang et al. (2011) and Wang Xiaolu et al. (2017) is used to characterize the degree of marketization in each region, and the model is added for robustness testing. Since the measurement indicators of the provincial marketization index have changed after 2008, this indicator cannot be directly added to the model, and the variables of the provincial marketization index need to be adjusted. The method is to set the dummy variable $\mathrm{D}$ and take the value after 2008 as 1 . The previous value is 0 , and the marketization index variable mard $=\operatorname{mar} x * \mathrm{D}$ is set. The slope of this variable is different in the two time periods around 2008, thus controlling the impact of the marketization index measurement adjustment. From the regression results in Table 5, after adding the marketization index, the overall political connections, previous 
political connections, and current political connections still have a significant positive impact on enterprise performance, and the performance of private enterprises with political connections is significantly higher than the performance of private enterprises without political connections indicates. It shows that the regression results are robust.

Table 5. The robustness tests of the influence of political connections on enterprise performance (adding marketization index)

\begin{tabular}{cccc}
\hline variables & Model (1) & Model (2) & Model (3) \\
\hline pcon & $5.370^{* * *}$ & & \\
fpoc & $(3.75)$ & $4.452^{* * *}$ & \\
& & $(3.89)$ & $5.795^{* * *}$ \\
cpoc & & & $(4.97)$ \\
& & & $1.288^{* * *}$ \\
mard & $1.249 * * *$ & $1.209 * *$ & $(2.71)$ \\
& $(2.64)$ & $(2.55)$ & yes \\
control variables & yes & yes & control \\
province & control & control & control \\
industry & control & control & control \\
year & control & control & 7872.000 \\
$\mathrm{~N}$ & 7872.000 & 7872.000 & 0.168 \\
r2 & 0.167 & 0.167 & \\
\hline
\end{tabular}

Note. $\mathrm{t}$ statistics in parentheses, $* \mathrm{p}<0.1, * * \mathrm{p}<0.05, * * * \mathrm{p}<0.01$.

Secondly, the anti-corruption movements may interfere with the behavioral motivation of enterprises to construct political connections and their performance impacts. Therefore, this paper refers to the research of Dang et al. (2015), Zhao and Meng (2016), takes the 18th National Congress of the Communist Party of China as the time node, and excludes samples after 2012 to avoid the impacts of anti-corruption after the 18th National Congress to retest the hypothesis of this paper. As shown in Table 6, the estimated results after transforming the regression samples show that total political connections (pcon), previous political connections (fpoc), and current political connections (cpoc) all have a significant positive impact on the performance of the company. It is proved that former conclusion keeps robust.

Table 6. The robustness tests of the influence of political connections on enterprise performance (deleting the samples after 2012)

\begin{tabular}{|c|c|c|c|}
\hline variables & Model (1) & Model (2) & Model (3) \\
\hline pcon & $\begin{array}{c}5.623 * * * \\
(3.68)\end{array}$ & & \\
\hline fpoc & & $\begin{array}{c}4.437 * * * \\
(3.59)\end{array}$ & \\
\hline сpoc & & & $\begin{array}{c}6.523 * * * \\
(5.22)\end{array}$ \\
\hline mard & $\begin{array}{c}1.629 * * * \\
(2.88)\end{array}$ & $\begin{array}{c}1.581 * * * \\
(2.79)\end{array}$ & $\begin{array}{c}1.689 * * * \\
(2.98)\end{array}$ \\
\hline control variables & yes & yes & yes \\
\hline Province & control & control & control \\
\hline industry & control & control & control \\
\hline year & control & control & control \\
\hline $\mathrm{N}$ & 7872.000 & 7872.000 & 7872.000 \\
\hline $\mathrm{r} 2$ & 0.156 & 0.156 & 0.158 \\
\hline
\end{tabular}

Note. $\mathrm{t}$ statistics in parentheses, $* \mathrm{p}<0.1, * * \mathrm{p}<0.05, * * * \mathrm{p}<0.01$.

\section{Mechanism of Influence and Empirical Analysis}

The above analysis shows that the political connections of private enterprises effectively affect the performance of the company. Next, we will further discuss the relationship between tax burden and non-productive activity expenditure in the political connections and the performance of private enterprises. 
Tax burden (txfe) is measured by table of tax burden rate, which is tax of this year/operating income. Non-productive activity expenditure (npex) has a complex construction, this paper uses the apportioned expenses paid by enterprises and public relations and entertainment expenses to describe non-productive expenditures of private enterprises, and uses operating income for standardized processing. Presently, the commonest method to test mediating effect is step-by-step method studied by Baron and Kenny. Due to the continuous improvement of testing methods and the increasingly abundant related theoretical research results, we use the intermediary effects testing process proposed by Wen and Ye (2004) to carry out the analysis. In this paper, there are five testing processes that are integrated into this detailed method. First, we estimate equation (3) to test the coefficient $\beta 1$ of the independent variable's political connections to the dependent variable's enterprise performance. If it is significant, we continue to do work in intermediary effects. Second, we test coefficient $\beta 1$ in equation (4) and coefficient $\gamma$ in equation (5) in turn. If both are significant, it proves political connections influence to enterprise performance by mediating factor, and then turn into the fourth step; if one of them does not work well, just go into the next step. Third, we perform a sobel test on the significance of the cross term coefficient. If it is significant, it may have mediating effects, just go into the fourth step; or indirect effects should not be so significant, then stop analyzing. Fourth, we test coefficient $\beta 1$ in equation (5), if it is not significant, that means direct effects is not significant. If significant, there is partial mediating effects, and go into the fifth step. Fifth, we compare the symbols of $\beta 1$ (equation 4 )* $\gamma($ equation 5 ) and $\beta 1$ (equation 3 ). If they have the same symbol, we report the ratio of the partial mediation effects to the total effects $\mathrm{ab} / \mathrm{c}$; if the sign is different, it is a cover effect, we report the absolute value of the ratio of the indirect effects to the direct effects $|\mathrm{ab} / \mathrm{c}|$. A three-step regression model is as below:

$$
\begin{aligned}
& \text { ROA }_{i}=\alpha+\beta_{1} x_{i}+\beta_{2} \text { empl }_{i}+\beta_{3} \text { agec }_{i}+\beta_{4} \text { alra }_{i}+\beta_{5} \text { ltass }_{i}+\beta_{6} \text { indc }_{i} \\
& +\beta_{7} \text { gend }_{i}+\beta_{8} \text { age }_{i}+\beta_{9} \text { edu }_{i}+\beta_{10} \text { ownp }_{i}+\text { year }+ \text { prov }+ \text { ind }+\varepsilon_{i} \\
& M_{i}=\alpha+\beta_{1} x_{i}+\beta_{2} \text { empl }_{i}+\beta_{3} \text { agec }_{i}+\beta_{4} \text { alra }_{i}+\beta_{5} \text { ltass }_{i}+\beta_{6} \text { indc }_{i} \\
& +\beta_{7} \text { gend }_{i}+\beta_{8} \text { age }_{i}+\beta_{9} \text { edu }_{i}+\beta_{10} \text { ownp }_{i}+\text { year }+ \text { prov }+ \text { ind }+\varepsilon_{i} \\
& \text { ROA }_{i}=\alpha+\beta_{1} x_{i}+\gamma M_{i}+\beta_{2} \text { empl }_{i}+\beta_{3} \text { agec }_{i}+\beta_{4} \text { alra }_{i}+\beta_{5} \text { ltass }_{i}+\beta_{6} \text { indc }_{i} \\
& +\beta_{7} \text { gend }_{i}+\beta_{8} \text { age }_{i}+\beta_{9} \text { edu }_{i}+\beta_{10} \text { ownp }_{i}+\text { year }+ \text { prov }+ \text { ind }+\varepsilon_{i}
\end{aligned}
$$

\begin{tabular}{|c|c|c|c|}
\hline variables & ROA & txfe & ROA \\
\hline \multirow[t]{2}{*}{ pcon } & $5.517 * * *$ & $1.877 * * *$ & $4.829 * * *$ \\
\hline & $(3.75)$ & $(6.62)$ & $(3.29)$ \\
\hline \multirow[t]{2}{*}{ txfe } & & & $0.366^{* * * *}$ \\
\hline & & & $(4.93)$ \\
\hline \multirow[t]{2}{*}{ empl } & $12.312 * * *$ & $0.350 * * *$ & $12.184 * * *$ \\
\hline & $(17.06)$ & $(3.62)$ & $(16.94)$ \\
\hline \multirow[t]{2}{*}{ ownp } & $-0.053 * * *$ & 0.004 & $-0.054 * * *$ \\
\hline & $(-2.69)$ & (1.40) & $(-2.77)$ \\
\hline control variable & yes & yes & yes \\
\hline province & control & control & control \\
\hline industry & control & control & control \\
\hline year & control & control & control \\
\hline $\mathrm{N}$ & 7872.000 & 7872.000 & 7872.000 \\
\hline $\mathrm{r} 2$ & 0.174 & 0.082 & 0.178 \\
\hline Sobel Z & & $3.953 * * *$ & \\
\hline
\end{tabular}

Table 7 and Table 8 respectively report the empirical test results of the overall political connections and different types of political connections that affect the performance of private enterprises by affecting corporate tax burdens.

Table 7. The results of the mechanism test of overall political connections affecting the performance of private enterprises (tax burden)

Note. $\mathrm{t}$ statistics in parentheses, $* \mathrm{p}<0.1, * * \mathrm{p}<0.05, * * * \mathrm{p}<0.01$. 
Table 8. The results of the mechanism test of the previous and current political connections affecting the performance of private enterprises (tax burden)

\begin{tabular}{|c|c|c|c|c|c|c|}
\hline \multirow{2}{*}{ variables } & \multicolumn{3}{|c|}{ Previous political connections } & \multicolumn{3}{|c|}{ Current political connections } \\
\hline & ROA & txfe & ROA & ROA & txfe & ROA \\
\hline \multirow[t]{2}{*}{ fpoc } & $4.398 * * *$ & $-0.382 *$ & $4.547 * * *$ & & & \\
\hline & $(3.75)$ & $(-1.78)$ & $(3.89)$ & & & \\
\hline \multirow[t]{2}{*}{ txfe } & & & $0.390 * * *$ & & & $0.323^{* * *}$ \\
\hline & & & $(5.25)$ & & & $(4.25)$ \\
\hline \multirow[t]{2}{*}{ срос } & & & & $6.035 * * *$ & $4.586 * * *$ & $4.554 * * *$ \\
\hline & & & & $(5.08)$ & $(22.08)$ & $(3.74)$ \\
\hline \multirow[t]{2}{*}{ ownp } & $-0.047 * *$ & 0.004 & $-0.049 * *$ & $-0.062 * * *$ & -0.002 & $-0.061 * * *$ \\
\hline & $(-2.37)$ & $(1.21)$ & $(-2.45)$ & $(-3.14)$ & $(-0.79)$ & $(-3.11)$ \\
\hline control variable & yes & yes & yes & yes & yes & yes \\
\hline province & control & control & control & control & control & control \\
\hline industry & control & control & control & control & control & control \\
\hline year & control & control & control & control & control & control \\
\hline $\mathrm{N}$ & 7872.000 & 7872.000 & 7872.000 & 7872.000 & 7872.000 & 7872.000 \\
\hline $\mathrm{r} 2$ & 0.174 & 0.076 & 0.178 & 0.175 & 0.133 & 0.178 \\
\hline Sobel z value & & $-1.684^{*}$ & & & $4.172 * * *$ & \\
\hline
\end{tabular}

In the results of regression, the first column in Table 7 shows that total political connections have significantly positive influence on enterprise performance $(\beta 1=5.517, \mathrm{p}<0.01)$. The second column shows total connections have significantly positively affects on its tax burden $(\beta 1=1.877, p<0.01)$, and coefficient $\gamma$ in the third column marks significantly $(\gamma=0.366, \mathrm{p}<0.01)$, this shows that tax burden is an intermediary factor for political connections to improve corporate performance. In the third column, coefficient $\beta 1=4.829$ is remarkably positive, and $\beta 1$ (equation 4$)^{*} \gamma($ equation 5 ) and $\beta 1$ (equation 3 ) having the same code, showing part of mediating effects. Mediating effects in all effects is $12.5 \%(=1.877 * 0.366 / 5.517)$.

Table 8 is the empirical testing result of different types of political connections influence on performance. For previous connections, the first column shows that previous political connections have significantly positive influence on enterprise performance. The second column shows the results that previous political connections have significantly positive influence on its tax burden $(\beta 1=4.398, \mathrm{p}<0.1)$. The second column shows that previous political connections are positively correlated to private enterprise performance $(\beta 1=-0.382, p<0.01)$, coefficient $\gamma$ in the third column marks significantly $(\gamma=0.390, \mathrm{p}<0.01)$, this shows that tax burden is the intermediary factors. Coefficient $\beta 1=4.547$ in the third column is significantly positive, but the opposite symbol between $\beta 1$ (equation 4$)^{*} \gamma($ equation 5 ) and $\beta 1$ (equation 3 ) is a masking effect, and the absolute value of the ratio of indirect effects to direct effects is $36.9 \%$ (|4.398*-0.382/4.547|). That is to say, the positive impacts of the previous political connections on private enterprise performance is obscured by the tax burden. For current political connections (cpoc), the results in the fourth column show that current political connection is significantly positively correlated with the performance of private enterprises $(\beta 1=6.035, p<0.01)$. The results in the fifth column show that current political connections significantly positively affect the corporate tax burden $(\beta 1=4.586, p<0.01)$, and coefficient $\gamma$ in the sixth column is significant $(\gamma=0.323, p<0.01)$, which indicates tax burden is also an intermediary factor for the current political connections to improve corporate performance. Coefficient $\beta 1=4.554$ in the sixth column is significantly positive, and $\beta 1$ (equation 4$)^{*} \gamma($ equation 5 ) and $\beta 1$ (equation 3 ) have the same sign. Part of the mediation effects are established, and the mediation effects account for $25.5 \%$ of total effects. In summary, tax burden can be regarded as an intermediary factor for political connections to improve corporate performance. Hypothesis 2 of this paper has been partly verified.

Table 9 and 10 respectively report the empirical test results of the overall political connections and different types of political connections affect the performance of private enterprises by influencing the expenditure of non-productive activities of enterprises. 
Table 9. The results of the mechanism test of the total political connections affecting the performance of private enterprises (non-productive activity expenditure)

\begin{tabular}{cccc}
\hline Variables & ROA & npex & ROA \\
\hline pcon & $5.517^{* * *}$ & $0.373^{* * * *}$ & $(3.48)$ \\
& $(3.75)$ & $(3.13)$ & $1.130^{* * * *}$ \\
npex & & & $(10.77)$ \\
& & 0.001 & $-0.053^{* * *}$ \\
ownp & $-0.053^{* * *}$ & $(0.56)$ & $(-2.72)$ \\
& $(-2.69)$ & yes & yes \\
control variables & yes & control & control \\
province & control & control & control \\
industry & control & control & 7872.000 \\
year & control & 7872.000 & 0.179 \\
$\mathrm{~N}$ & 7872.000 & 0.048 & $3.005^{* * *}$ \\
r2 & 0.174 & & \\
\hline
\end{tabular}

Note. $\mathrm{t}$ statistics in parentheses, ${ }^{*} \mathrm{p}<0.1, * * \mathrm{p}<0.05, * * * \mathrm{p}<0.01$.

Table 10. The results of the mechanism test of previous and current political connections affecting the performance of private enterprises (non-productive activity expenditure)

\begin{tabular}{|c|c|c|c|c|c|c|}
\hline \multirow{2}{*}{ variables } & \multicolumn{3}{|c|}{ Previous political connections } & \multicolumn{3}{|c|}{ Current political connections } \\
\hline & ROA & npex & ROA & ROA & npex & ROA \\
\hline fpoc & $\begin{array}{c}4.398 * * * \\
(3.75)\end{array}$ & $\begin{array}{c}0.173 * * \\
(2.10)\end{array}$ & $\begin{array}{c}4.201 * * * \\
(3.59)\end{array}$ & & & \\
\hline npex & & & $\begin{array}{c}1.142^{* * * *} \\
(10.86)\end{array}$ & & & $\begin{array}{c}1.122 * * * \\
(10.56)\end{array}$ \\
\hline срос & & & & $\begin{array}{c}6.035^{* * * *} \\
(5.08)\end{array}$ & $\begin{array}{c}0.311 * * * \\
(4.79)\end{array}$ & $\begin{array}{c}5.686^{* * * *} \\
(4.79)\end{array}$ \\
\hline ownp & $\begin{array}{c}-0.047 * * \\
(-2.37)\end{array}$ & $\begin{array}{l}0.001 \\
(0.75)\end{array}$ & $\begin{array}{c}-0.048 * * \\
(-2.42)\end{array}$ & $\begin{array}{c}-0.062 * * * \\
(-3.14)\end{array}$ & $\begin{array}{l}0.000 \\
(0.09)\end{array}$ & $\begin{array}{c}-0.062 * * * \\
(-3.15)\end{array}$ \\
\hline $\begin{array}{c}\text { control variable } \\
\text { province }\end{array}$ & $\begin{array}{l}\text { yes } \\
\text { control }\end{array}$ & $\begin{array}{c}\text { yes } \\
\text { control }\end{array}$ & $\begin{array}{l}\text { yes } \\
\text { control }\end{array}$ & $\begin{array}{c}\text { yes } \\
\text { control }\end{array}$ & $\begin{array}{c}\text { yes } \\
\text { control }\end{array}$ & $\begin{array}{c}\text { yes } \\
\text { control }\end{array}$ \\
\hline industry & control & control & control & control & control & control \\
\hline year & control & control & control & control & control & control \\
\hline $\mathrm{N}$ & 7872.000 & 7872.000 & 7872.000 & 7872.000 & 7872.000 & 7872.000 \\
\hline $\mathrm{r} 2$ & 0.174 & 0.047 & 0.179 & 0.175 & 0.048 & 0.180 \\
\hline Sobel Z & & $2.066^{* *}$ & & & $4.360 * * *$ & \\
\hline
\end{tabular}

Note. $\mathrm{t}$ statistics in parentheses, ${ }^{*} \mathrm{p}<0.1, * * \mathrm{p}<0.05, * * * \mathrm{p}<0.01$.

In Table 9, the results in the first column show that total political connections are significantly positively correlated with the performance of private enterprises $(\beta 1=5.517, \mathrm{p}<0.01)$. The results in the second column show that total political connections significantly positively affect non-productive activity expenditure of enterprises $(\beta 1=0.373, p<0.01)$, and the coefficient $\gamma$ in the third column is significant $(\gamma=1.13, p<0.01)$, which shows non-productive activity expenditure is an intermediary factor for political connections to improve corporate performance. The coefficient $\beta 1=5.096$ in the third column is significantly positive, and $\beta 1$ (equation $4)^{*} \gamma($ equation 5) and $\beta 1$ (equation 3) have the same sign. Part of the mediation effects are established, and the mediation effects account for $7.6 \%$ of the total effects.

In Table 10, in terms of previous political connections, the first column results show that previous political connections are significantly positively correlated with private enterprise performance $(\beta 1=4.398, p<0.01)$. The results in the second column show that previous political connections significantly positively affect non-productive activity expenditure of enterprises $(\beta 1=0.173, \mathrm{p}<0.01)$, and the coefficient $\gamma$ in the third column is significant $(\gamma=1.142, \mathrm{p}<0.01)$, which indicates non-productive activity expenditure is an intermediary factor. Coefficient $\beta 1=4.201$ in the third column is significantly positive, and $\beta 1$ (equation 4)* $\gamma($ equation 5) and $\beta 1$ (equation 3 ) have the same sign. Part of the mediation effects are established, and the mediation effects account for $4.5 \%$ of the total effects. In terms of current political connections, the results in column 4 show that current 
political connections are significantly positively correlated with the performance of private enterprises $(\beta 1=6.035, p<0.01)$. The results in the fifth column show that the current political connections significantly positively affects enterprises' expenditure on non-productive activities $(\beta 1=0.311, p<0.01)$, and coefficient $\gamma$ in the sixth column is significant $(\gamma=5.686, \mathrm{p}<0.01)$, which shows that non-productive activity expenditure is also an intermediary factor for current political connections to improve corporate performance. In the sixth column, coefficient $\beta 1=1.122$ is significantly positive, and $\beta 1$ (equation 4$)^{*} \gamma($ equation 5 ) and $\beta 1$ (equation 3 ) have the same sign, part of the mediation effects are established, and the mediation effects account for $29.3 \%$ of the total effects. In summary, non-productive activity expenditure can be regarded as an intermediary factor for political connections to improve corporate performance. Hypothesis 3 of this paper has been proven.

\section{Conclusions}

According to the analysis above, three main conclusions can be drawn in this paper: firstly, enterprises with political connections have better performance than those without political connections; secondly, different types of political connections all have positive effects on the performance of private enterprises, and compared with previous political connections, current political connections have more positive effects on the performance of private enterprises; thirdly, tax burden and non-productive activity expenditure are mediating factors in the relationship between and private enterprise performance.

The relevant empirical results also have important implications for Chinese government and Chinese private enterprises. Firstly, the government should pay attention to the law of industrial development, simplify the structure of government, continue to explore and build a perfect institutional environment, promote marketization and energize the competitiveness in market with less impacts of non-price competition. Secondly, private enterprises should rationally construct appropriate political connections. Judging from the results of this paper, although both types of political connections can improve corporate performance, previous connections are unstable and expensive to maintain; current political connections affect enterprise more significantly but it doesn't mean certain profits. Therefore, to intensify the real ROA in enterprises, private enterprises need to pay attention to the acquisition of various core resources, control their various operating costs (including politically-related costs), build their own core competitiveness and truly increase the return on assets. At the same time, the conclusions of this paper also imply policy implications. There is a trade-off between political connections and enterprise government. Entrepreneurs should devote more time to the management and operation of enterprises, reduce the amount of unnecessary time spent on government and other external factors due to maintaining political connections.

\section{References}

Bailey, D. H. (1966). The effects of corruption in a developing nation. Western Political Quarterly, 19(4), 719-732. https://doi.org/10.1177/106591296601900410

Chen, Y. S., \& Zhu, S. (2009). Political connection, institutional environment and capital investment of listed companies. Journal of Finance and Economics, 35(12), 27-39. http://doi.org/10.16538/j.cnki.jfe.2009.12.003

Faccio, M. (2006). Politically connected firms. American Economic Review, 96(1), 369-386. https://doi.org/10.1257/000282806776157704

He, X. B., Zheng, G., \& Teng, Y. (2019). The types of political connections and corporate performance of private entrepreneurs. Academia Bimestrie, 6, 73-81. http://doi.org/10.16091/j.cnki.cn32-1308/c.2019.06.012

Leys, C. (1965). What is the problem about corruption?. Journal of Modern African Studies, 3(2), 215-230. https://doi.org/10.1017/S0022278X00023636

Li, C. X., Gan, S. D., \& He, Y. C. (2013). Research on political connection and corporation over-investment behavior - evidences from Chinese listed companies from 2008 to 2010. Shanghai Journal of Economics, 5 , 63-68. http://doi.org/10.19626/j.cnki.cn31-1163/f.2013.05.007

Li, H., \& Zhang, Y. (2007). The role of managers' political networking and functional experience in new venture performance: Evidence from China's transition economy. Strategic Management Journal, 28(8), 791-804. https://doi.org/10.1002/smj.605

Li, W. A., \& Xu, Y. K. (2012). Political connection styles, institutional environment and the productivity of private listed corporations. Journal of Management Science, 25(2), 1-12.

Niessen, A., \& Ruenzi, S. (2010). Political connectedness and firm performance: Evidence from Germany. German Economic Review, 11(4), 441-464. https://doi.org/10.1111/j.1468-0475.2009.00482.x 
Peng, H. F., Zhang, W. H., \& Zhang, X. (2014). Bank relationship, political relevance and the allocation efficiency of credit resource - empirical analysis on Chinese listed companies. Modern Economic Science, 5 , 52-60.

Peng, Z. W., \& Li, Y. X. (2019). Does government support and R\&D spillover improve civil-military integration firms' product quality: From the perspective of market competition. Journal of Xiangtan University (Philosophy and Social Sciences), 43(5), 77-82. http://doi.org/10.13715/j.cnki.jxupss.2019.05.012

Su, Z. Q., Fung, H., \& Yau, J. (2013). Political connections and corporate overinvestment: Evidence from China. International Journal of Accounting and Information Management, 21(4), $285-296$. https://doi.org/10.1108/IJAIM-02-2013-0006

Yang, P. P., Xu, Z. W., \& Li, X. S. (2015). Empirical study on enterprise performance affected by private entrepreneur's social capital and dynamic capabilities. Journal of Shanxi University of Finance and Economics, 37(9), 101-112. http://doi.org/10.13781/j.cnki.1007-9556.2015.09.009

Zhang, W. Y. (2005). Enterprise ownership and late-development advantage in China. Economic Perspectives, 2 , $3-5$.

Zimmerman, J. L. (1983). Taxes and firm size. Journal of Accounting and Economics, 5, 119-149. https://doi.org/10.1016/0165-4101(83)90008-3

\section{Copyrights}

Copyright for this article is retained by the author(s), with first publication rights granted to the journal.

This is an open-access article distributed under the terms and conditions of the Creative Commons Attribution license (http://creativecommons.org/licenses/by/4.0/). 